\title{
The link between concussion and inflammation
}

Steven Karceski, MD

Neurology ${ }^{\circledR}$ 2019;93:e526-e529. doi:10.1212/WNL.0000000000007867

In their article "Acute elevation of serum inflammatory markers predicts symptom recovery after concussion," Nitta and coauthors ${ }^{1}$ studied the connection between inflammation and head trauma. More specifically, they looked at the connection between inflammation and mild brain injury in American football players.

Using specific blood tests, they measured certain parts of the blood that reflect inflammation in the body. They checked these blood tests at many different time points after the head trauma. They found that some of these blood tests were elevated after a concussion. Football players who had a concussion and showed inflammation on the blood tests recovered more slowly than those who did not.

\section{Background}

Head injuries are very common, especially in athletes. The most common head injury is concussion. It is estimated that there are almost 4 million sports-related concussions in the Unites States each year. Although there are many ways to grade the severity of concussions, most use loss of consciousness as the measure. In other words, a concussion without loss of consciousness is thought to be a mild concussion. One that causes loss of consciousness is more severe. This study focused on athletes who had mild traumatic brain injury, or mild concussion.

The connection between concussion — or brain injury—and inflammation has been known for years. Inflammation is one of the body's responses to injury. As a response to injury, when inflammation occurs, the body produces several different substances such as cytokines.

In response to moderate or severe brain injury, it has been shown that there are increases in the cytokines, including interleukin- $1 \beta$, interleukin-6 (IL-6), interleukin-10, and tumor necrosis factor. They are increased within 24 hours of the injury. In people with more severe brain injury, the presence of these was associated with reduced consciousness as well as a higher risk of dying from the injury.

The inflammatory response to mild traumatic brain injury is still not clear. Some prior studies have shown that after mild traumatic brain injury, certain cytokines increased. When the cytokines were higher, some studies suggested that the time to recovery was longer. To clarify this, the current study assessed specific blood tests after mild concussion. Not only did the authors measure these right after the head injury occurred, but they checked participants' blood again for several weeks thereafter.

\section{How was the study done?}

The investigators started by asking high school and college athletes in Wisconsin if they would participate in a head injury study. In 2015 and 2016, 857 athletes agreed. All the athletes were interviewed, answered questionnaires, and had cognitive testing, including the Wechsler Test of Adult Reading (WTAR), both before and after their concussion. Cognitive testing measures a person's reasoning and concentration skills.

During the study, there were 90 concussions. To be sure that there were no other factors that could confound the results, the investigators narrowed down the concussions from 90 to 43 .

\section{RELATED ARTICLE}

Acute elevation of serum inflammatory markers predicts symptom recovery after concussion

Page 203 
Confound is another way of saying confuse. Some of the factors that excluded athletes were prior moderate or severe brain injury, a history of seizures, migraines (or recurrent headaches), inflammatory illnesses, and a history of illicit drug use.

When athletes had a concussion, they were evaluated in several ways. First, the athletes were evaluated by the team physician or the team-certified athletic trainer. Using criteria developed by the Centers for Disease Control and Prevention, the team doctor or trainer made the determination of (1) a concussion and (2) severity of the concussion. Using the Sport Concussion Assessment Tool, 3rd edition (also called the SCAT3), the athletes' concussion symptoms were scored. These scores were used to determine the concussion severity.

The main focus of the current study was the blood testing. Serum tests were measured at baseline (before head injury) and at several time points after the concussion: 6 hours, 24-48 hours, and at 8,15 , and 45 days after the mild head injury.

In a study, there should be a comparison group, called the control group. In this study, when an athlete had a concussion, the authors immediately searched the 857 athletes for an uninjured match. In other words, they looked for another athlete of the same grade (high school or college), level of play, and team position. They found 47 uninjured athletes who matched.

\section{What did the researchers find?}

The researchers found that the athletes with concussion had higher concussion (SCAT3) scores at 6 hours and 24-48 hours after injury, as compared to the uninjured athletes. They also found that interleukin-1RA and IL- 6 were elevated when measured 6 hours after the head injury. When athletes had elevated IL-6 at the 6-hour point, the time to recovery was longer. Saying this, the athletes had recovered from their mild concussion in about 9 days.

\section{What does this mean?}

The current study supports prior studies in that it shows a relationship among mild concussion, inflammation, and time to recovery. As studies continue, we may better understand the connection between injury and inflammation. Perhaps this will lead to new treatments. Following concussion, if these serum tests were abnormal, a treatment could be given to shorten or improve the time and extent of recovery after brain injury. 


\section{About Concussion}

Steven Karceski, MD

Neurology ${ }^{\circledR}$ 2019;93:e526-e529. doi:10.1212/WNL.0000000000007867

\section{What is a concussion?}

Simply put, a concussion is a brain injury that affects brain function. It is usually caused by a blow to the head. However, concussion can also occur in people who were close to an explosion. Even though their head was not hit by an object, they still have the effects of the pressure wave that the explosion causes. The American Academy of Neurology defines concussion as "trauma-induced alteration in mental status that may or may not involve loss of consciousness." In other words, a person who has a concussion does not need to pass out as a result of the injury. In fact, many people who have had a concussion never lost consciousness.

Almost any sport can cause a head injury and concussion. American football and ice hockey players have the most concussions. However, concussions also occur in European football (soccer), wrestling, basketball, baseball, and softball. Mostly, concussions occur during games. Less often, head injuries and concussions occur during sports practice. In college sports, concussion is common. Another study reported the percentage of head injuries as follows: ice hockey (12.2\%), football ( $8 \%)$, and soccer (4.8\%). In high school students, the authors of the same study estimated that up to $8 \%$ have had a concussion. ${ }^{3}$

The symptoms of concussion vary. Common complaints are headache, vacant stare, confusion, dizziness, memory problems (or trouble with thinking and attention), poor balance, irritability (or depression), and vomiting. However, not every person who has a concussion will have all of these symptoms. For some people, the symptoms may be very mild.

There are several ways that concussions are graded. The lowest is grade I. In grade I concussion, the person is confused for less than 15 minutes, but never loses consciousness. Grade II means confusion without loss of consciousness for more than 15 minutes. Grade III means that the athlete lost consciousness. Any loss of consciousness should be evaluated by a neurologic examination and some type of imaging of the brain (MRI or CT).

Although many studies have focused on concussion in athletes, there is another at-risk group: soldiers. It is estimated that over 300,000 soldiers in Iraq have had some type of head injury. ${ }^{4}$ The Department of Veterans Affairs is very interested in concussion. It is conducting its own studies, but it is clear that studies of head injury in athletes can be important to many other people (and vice versa).

\section{Postconcussion syndrome}

Most athletes recover fully from a concussion in hours, days, or (at most) weeks. The time to full recovery depends on the person, the severity of the injury, and the way in which the injury occurred. In addition, research has suggested that having a second concussion before recovering from the first can lead to serious (and long-lasting) problems with thinking, attention, concentration, and other brain functions. For instance, after many repeated head injuries and concussions, a boxer can start to have the kinds of problems that happen when people have Alzheimer disease.

\section{Treatment of concussion}

The most important treatment is prevention. More specifically, parents and athletes need to consider how they can prevent head injuries from happening. In some sports, like ice hockey, protective equipment is mandatory. 


\section{Additional resources}

Brain \& Life

brainandlife.org/

Brain Injury Association of America

biausa.org

National Injury Prevention Foundation

thinkfirst.org

\section{References}

1. Nitta M, Savitz J, Nelson L, et al. Acute elevation of serum inflammatory markers predicts symptom recovery after concussion. Neurology 2019;93:e497-e507.

2. Langois JA, Rutland-Brown W, Waid MM. The epidemiology and impact of traumatic brain injury: a brief overview. J Head Trauma Rehabil 2006;21:375-378.

3. McCree M, Guskiewicz KM, Marshall SW, et al. Acute effects and recovery time following concussion in collegiate football players: the NCAA Concussion Study. JAMA 2003;290:2556-2563.

4. Maruta J, Lee SW, Jacobs EF, Ghajar J. A unified science of concussion. Ann NY Acad Sci 2010;1208:58-66. 


\section{Neurology}

\section{The link between concussion and inflammation \\ Steven Karceski \\ Neurology 2019;93;e526-e529 \\ DOI 10.1212/WNL.0000000000007867}

This information is current as of July 29, 2019

\section{Updated Information \& Services}

References

Permissions \& Licensing

Reprints including high resolution figures, can be found at: http://n.neurology.org/content/93/5/e526.full

This article cites 4 articles, 1 of which you can access for free at: http://n.neurology.org/content/93/5/e526.full\#ref-list-1

Information about reproducing this article in parts (figures,tables) or in its entirety can be found online at:

http://www.neurology.org/about/about_the_journal\#permissions

Information about ordering reprints can be found online:

http://n.neurology.org/subscribers/advertise

Neurology ${ }^{\circledR}$ is the official journal of the American Academy of Neurology. Published continuously since 1951, it is now a weekly with 48 issues per year. Copyright (O 2019 American Academy of Neurology. All rights reserved. Print ISSN: 0028-3878. Online ISSN: 1526-632X.

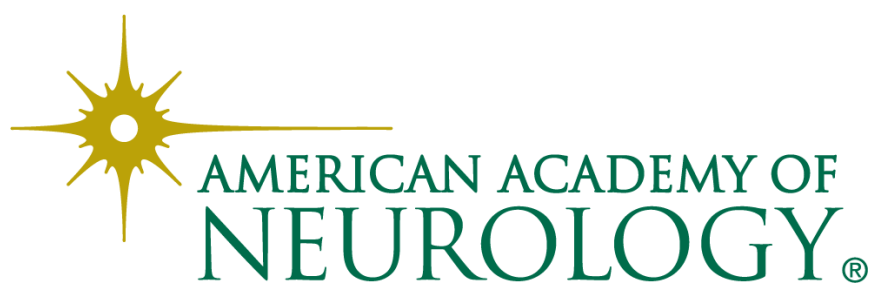

